\title{
ПОГЛЯД ЗАРУБІЖНИХ ТА ВІТЧИЗНЯНИХ НАУКОВЦІВ НА ПРОБЛЕМУ МЕТАКОГНІТИВНИХ ЗДІБНОСТЕЙ
}

\author{
Захарчук Тетяна Миколаӥвна \\ Практичний психолог, м.Сарни Рівненської обл. Україна, аспірант НУ «Острозька академія»
}

DOI: https://doi.org/10.31435/rsglobal_ws/31082019/6645

\section{ARTICLE INFO}

Received: 18 June 2019

Accepted: 15 August 2019

Published: 31 August 2019

\section{KEYWORDS}

the purpose of cognitive development, the effectiveness of learning, metacognitive ability, the purpose of cognition, the purpose of thinking, metapamyat, thinking operations.

\begin{abstract}
The article deals with theoretical concepts and approaches to the problem of meta cognitive abilities, psychological aspects of the formation and development of meta processes in adulthood and childhood. The views of scientists on the problems of the purpose of processes in psychological science are revealed. The peculiarities of the development of mental operations within the framework of metacognitivism are considered, based on the views of foreign and domestic scholars.
\end{abstract}

Citation: Zakharchuk T. N. (2019) The View of Foreign and Domestic Scientists on the Problem of Methodological Characteristics. World Science. 8(48), Vol.3. doi: 10.31435/rsglobal_ws/31082019/6645

Copyright: (C) 2019 Zakharchuk T. N. This is an open-access article distributed under the terms of the Creative Commons Attribution License (CC BY). The use, distribution or reproduction in other forums is permitted, provided the original author(s) or licensor are credited and that the original publication in this journal is cited, in accordance with accepted academic practice. No use, distribution or reproduction is permitted which does not comply with these terms.

Постановка проблеми. Протягом останніх років все більше уваги приділяється покращенню та зміцнення ефективності окремих видів людської зокрема навчальної діяльності учнів, сучасні автори звертають увагу на так звані метакогнітивні процеси, а саме ті які сприяють кращому засвоєнню, обробці та відтворенні інформації., спираючись на так званий мета когнітивний досвід, знання, відчуття, планування та стратегії. В психологічній літературі метапізнання характеризується, як розуміння суб'єкта пізнання власних знань про особливості роботи власної когнітивної сфери, іiї активності та можливості в процесі пізнавальної діяльності. Сам процес метапізнання має прояв знань яким чином, використовувати конкретні стратегії та дії для вирішення певних задач. Освітня діяльність вимагає від особистості гнучкості та ефективності у процесі оволодіння новітньої інформації, а також можливість подальшої багаторівневої та структурної роботи спрямованої над вирішення складних завдань. За останніми сучасними дослідженнями, вчені дійшли висновку, що більшість людей не мають чіткого розуміння про те наскільки вони можуть бути проінформовані та обізнані у розв'язанні певних проблемних питань які стосуються не лише навчальної діяльності але і їх повсякденної трудової, особистісної та суспільної взаємодії. Виходячи з вище сказаного слід відмітити, про важливість здатності людини чітко усвідомлювати можливість контролю безпосередньо власної когнітивної діяльності, яка забезпечує ефективність при вирішенні проблемних питань, що у свою чергу можуть гальмувати та пригнічувати інтелектуальну діяльність. За останні роки досліджень у науковій психології 3'явилось поняття «мета когнітивних здібностей» - тобто здібностей які сприяють ефективному розумінню особистості діяльності власної пізнавальної сфери у процесі роботи пов'язаної 3 обробкою та інтеграцією інформації в повсякденному використанні.

Аналіз останніх досліджень і публікацій. Дослідження проблем метапізнання, мета когнітивних здібностей, визначенню їхніх функцій та структурних компонентів окрім Дж. Флейвелла присвячували наукові праці А. Браун, Д. Мошман, Т. О.Нелсон, Р.Шоу, Г. Саймон, Дж. Міллер, Р. Аткінсон, Р. Клюве, Л. Наренс, А. Коріат Т. Чернокова, М. Холодна, 
А. Карпов, С. Савін, А. Фомін та багато інших [4, с.6-7]. Суть розуміння понять пов'язаних 3 метапізнанням мають прояв у різних наукових психолого-педагогічних сферах, які у свою чергу переплітаються із розумінням суті самого пізнання як такого, 3 точки зору науковотеоретичних позицій, а також теоретичним аналізом понять або ж іншими словами термінів, які мають безпосереднє відношення до сфери метапроцесів - метакогнітивна усвідомленість, метакогнітивний досвід, метакогнітивна активність, самоконтроль, саморегуляція, рефлексія тощо. Метакогнітивні процеси - це особлива, стратегічна форма прояву психіки людини, яка об'єктивно розкриває суть проблеми здібностей на основі функціонально-генетичної парадигми. При цьому визнається існування особливого класу здібностей - мета здібностей. Першоджерелом метапізнавального напрямку в онтогенезі виступили праці Жана Піаже які в майбутньому сьогоденні знайшли своє відображення в роботах Дж. Флейвелла, якого вважають одним із перших дослідників метапроцесів. Метапізнавальні процеси здебільшого в психологічн-науковій літературі визначаються в рамках концептуально-інтелектуального напрямку. Такі вчені як А. Браун, Дж. Вілсон, А.В. Карпов, М.А. Холодна, відкривають визначення структурним особливостям та проявам метапсихічних процесів в онтогенезі. Проаналізувавши останні дослідження в галузі метапізнавальних процесів, слід звернути увагу на теорію Т.Е. Чернокової. Сам процес метапізнання розглядається дослідницею, як накопичення інформаційних знань суб'єкта власне про пізнавальну діяльність як таку загалом, а також про особливість психічної сфери суб'єкта, яка дозволяє суб'єкту пізнавальної діяльності регулювати iї, відтворювати у потрібний момент, припиняти іiі та безпосередньо застосовувати. Сама ж структура метапізнання за Т.Е. Черноковою має наступні складові - це контроль та програмування дій, а також ціле покладання. В свою чергу ряд науковців таких як Д.Ріглі, П.Шетц, Р.Гланц і С.Вайнштейн розглядають зокрема метакогнітивні процеси як свідоме розуміння суб'єктом власної мисленнєвої діяльності а також розуміння стратегій, вибору та планування своєї безпосередньої діяльності. Зокрема ученими, здійснено аналіз поняття «моніторингу пізнавальної діяльності»[17, с. 265-280].

Мета дослідження $є$ теоретичний аналіз поглядів та концепцій щодо проблематики мета когнітивних здібностей у психологічній науці.

Виклад основного матеріалу. Останнім часом у світовій та вітчизняній психологічній науці все частіше стали з'являтись дослідження пов'язані 3 проблемами теоретикометодологічних питань виникнення так званих «мета когнітивних здібностей» не тільки дорослих але й дітей дошкільного та шкільного віку у процесі навчальної діяльності.

Одне із найперших направлень висвітлено в роботах школи Ж.Піаже [1, с.128-134]. Жан Піаже як основоположник так званої періодизація розвитку метапізнавальних феноменів, в тому числі рефлексії і описання феноменології усвідомлення дитиною своїх власних пізнавальних процесів в різному віці. В екпериментальних дослідженнях в рамках цього напрямку отримано багато даних про сприйняття та вміння дітьми різного віку розрізняти та диференціювати власні думки та наміри стосовно своєї інтелектуальної, а також описано феноменологію усвідомлення дитиною своїх пізнавальних процесів в ранньому віці.

В контексті саме наукової психології поняття «метапізнання» 3'являється у кінці ХХ століття, а точніше у 1976 роботу над ним здійснив дослідник у галузі когнітивної психології Дж. Флейвелл. Саме Дж. Флейвелл дослідивши сферу людських знань, дійшов висновку про можливості способу контролю та активації людиною власної пізнавальної діяльності. Він же являється одним з перших хто став досліджувати та вивчати метапроцеси як особливий вид здібностей людини. Зокрема більшість авторів вважають Дж. Флейвела початківцем мета когнітивного напрямку в сучасній психології. Значний вплив на формування поглядів Дж.Флейвелла мали роботи виконані саме у школі Ж.Піаже. У своїй публікації «Психологія розвитку Жана Піаже» Дж. Флейвел розвиває ідеї Ж. Піаже, розглядаючи метапізнання як основу житейської мудрості. Науковцем було розроблено та досліджено такі ключові складові метапізнання: метакогнітивні знання; метакогнітивний досвід; метакогнітивні цілі та стратегії [1 с.130-134].

За Дж.Флейвеллом, метагонітивні знання та мета когнітивний досвід дають можливість суб'єкту пізнавальної діяльності здійснювати аналіз та внутрішню рефлексію власних інтелектуальних процесів. Метакогнітивні знання - це знання щодо особливостей власних пізнавальних процесів таких як пам'ять, мислення, сприймання. 
Власне сам досвід особистості, свідомий, який пов'язаний з інтелектуальними діями та процесами людини у процесі взаємодії з іншими суб'єктами, будь-якої діяльності, навчальної зокрема Дж.Флейвелл трактує як - метакогнітивний досвід.

Саме контроль та регуляція власне діяльності пізнання відображають суть метастратегій та метацілей. Оскільки, на думку Дж.Флейвелла, пізнавальну діяльність регулюють когнітивні процеси, а регуляцію та контроль - метакогнітивні. [17, с.35-60, 18, с.231-235]. За висновками Дж. Флейвела, у дошкільний період відбувається активний розвиток метакогнітивної здібності, саме у цей час у особистості, завдяки розвитку саморегуляції здійснюється планування власних дій, прийняття рішення й вибір ефективних стратегій щодо здійснення рішення при виконанні поставлених завдань. Активний розвиток так званих метакогнітивних здібностей призводить до метапізнавального розвитку самої особистості і характеризується як ефективний аналіз та контроль власної психічної діяльності, а також керування своїми цілями, діями та безпосередньо знаннями у тій чи іншій сфері. Можливість суб'єкта діяльності планувати власні дії відносно власних знань включаючи особливості стратегічної активності та рефлексивності допомагає активно та швидко реагувати на можливі різкі зміни у діяльності та створенні відносно нових форм діяльності та механізмів взаємозв'язку. Усі ці форми розкривають ключові компоненти мета пізнання. [19, с.3-34].

Послідовниця Дж. Флейвела, американська дослідниця Анна Браун розділила метапізнання на дві своєрідні структури: власне знання про суб'єктивне пізнання та безпосередню регуляцію власного пізнання. Що саме змушує людей розмірковувати над власними діями, а також аналізувати свою інтелектуальну діяльність,саме це та багато інших питань наштовхнуло дослідницю на вивчення так званого знання про людське пізнання. Яким чином воно відбувається, як його можна проаналізувати, розкрити, дослідити а найголовніше як у своїй діяльності розуміє це сама особистість - це всі ті та безліч інших питань над якими працювала Анна Браун. Така інформація у розумінні людей найчастіше описується та аналізується словами «знаю, що...» [1, с.130]. Також А. Браун досліджуючи процеси мислення, особливу увагу звертала на те яким саме чином у свідомості людини функціонують процеси регуляції та планування саме мисленнєвих дій та операцій, а також яким чином мотивація індивіда залежить від саме складності та специфіки поставлених інтелектуальних завдань у іiі безпосередній діяльності і яким чином вони можуть у подальшому регулювати та впливати на результативність виконаної роботи.[2, с.413]. Метакогнітивні процеси А. Браун описувала, як свідомі механізми метамисленнєвих дій, що активно сприяють залученню особистості до пізнавальної діяльності, вирішенню мисленнєвих задач та цілей поставлених у процесі роботи. А.Браун також відмітила, що людина використовує метамислення лише для вирішення задач із високим рівнем складності, виходячи з цього метамислення виступає як особлива здатність людини розмірковувати про свою власну інтелектуальну діяльність[5, с. 244-248 ].

М. Р. Клюве широко визначає специфіку метакогнітивних знань: на пізнавальному рівні представленні знання відповідаючи тому що суб'єкт має певні знання відносно певної галузі дійсності, а метакогнітивний рівень $є$ включенням сфери даних, які відносяться до самого вирішення безпосередньо поставленої проблеми[17С.429-455].

Дж. Вілсон здійснює акцент на так званій метакогнітивній обізнаності тобто, знанні суб'єкта про власні плани, ідеї та стратегії навчання, здійснюючи при цьому метакогнітивну оцінку, а саме судження про свої розумові можливості й обмеження у вирішенні конкретної тої чи іншої проблемної ситуації. I звичайно, як більшість дослідників метакогнітивного напрямку звертає увагу на регулятивну діяльність суб'єкта у процесі мета пізнання. Суть якої заключається у варіативних та ситуативних моделей мисленнєвих процесів та мисленнєвої діяльності та пошуку інтерактивних вирішень проблемних ситуацій[14,19].

Слід також звернути увагу на так звану ієрархічну модель мета пізнавальних процесів. Одними із авторів є С. Тобіас та Т.Еверсон. За викладами їх теорії метапізнання - це ціле комплексне утворення когнітивних процесів загалом, умінь, знань власних пізнавальних процесів, а також відстеження та контроль процесів освоєння нових знань та ефективність впровадження їх у мисленнєвій діяльності. Дані компоненти утворюють ієрархічну модель, у якій метакогнітивні навики знання моніторингу є передумовою для певних метакогнітивних вмінь, які сприяють оволодінню новими навиками та властивостями у ході діяльності, а метакогнітивний контроль у свою чергу $\epsilon$ важливим компонентом на всіх рівнях цієї ієрархічної моделі. 
У продовженні теорії, учений Р.Стернберг, також виділяє певні метакомпоненти. Метакомпоненти, на його думку, процеси які сприяють управлінню та керуванню обробки інформації, які включають в себе наступні компоненти: визнання існування проблеми; іiі усвідомлення та обрання можливих рішень; вибір стратегії; вибір ментальної репрезентації; розподіл існуючих ресурсів; контроль за процесом вирішення задачі; оцінка ефективності результату. За теорією Р. Стернберга метакомпоненти $є$ найвищими компонентами регулювання та виконання на певному рівні знань та умінь які сприяють в оволодіванні новими багаторівневими знаннями та вміннями [18, с.231-235].

Також слід згадати про так звану імпліцитну теорію розвитку свідомості. Представниками його $є$ Р.Джонсон, К.Уеллмен, Н.Пернер. Даний напрямок інтенсивно розвивається на даний час, починаючи 3 кінця 1980-х рр. в рамках даного напрямку було опубліковано не один десяток статей, які відкривають структурний компонент метакогнітивних функцій та стратегій. Дослідження проводились зокрема 3 дітьми дошкільного віку. Обумовлено це тим, що в даному віці в перше проявляються метакогнітивні функції: діти починають аналізувати можливі варіанти вирішення різного роду проблемних ситуацій, також програвати у процесі сюжетно-рольової діяльності дії варіативних ситуацій у безпосередній взаємодії з однолітками та дорослими. 3 точки зору досліджень у галузі теорії свідомості дітей, мета когнітивні феномени, які відстежуються саме у дитячому віці, розкривають саме розуміння дітей оточуючого світу, його характеристику та ментальність, що дає дітям не лише відчути а й зрозуміти особливості взаємодії та взаємозв'язку 3 іншими у величезному суспільному існуванні, а й приймати відповідні дії створювати можливі варіанти власної поведінки та реакції на дії інших людей, виходячи уже з власного мета когнітивного досвіду, якого вони набувають у ході постійної діяльності, як самостійної так і колективної.

Великий внесок у розвиток метакогнітивного напрямку було здійсненно сучасними науковцями та дослідниками.

Б.М.Величковський один із вчених, який розглядав структуру метапізнання у взаємодії наступних компонентів: метапродукти пізнання, метапроцедури уяви, метапроцедури вербалізації й комунікації, процеси становлення інтенціонально-особистісних та вольових контекстів [3].

Велику роль у вивченні мета процесів відіграли роботи російського досдіника А.В. Карпова. У своїх роботах А.В.Карпов розглядає метаздібності, як особливий вид здібностей людини до складу яких він включає, здібності метамотиваційної регуляції і метаемоційного контролю, тобто іншими словами під метаздібностями вчений розуміє можливість людини власної контрольованої пізнавальної поведінки, що сприяє ефективному оволодінні інтерактивними методами знання [6, с.352]. У співавторстві із І.М. Скитяєвою А.В. Карпов вважають, однією із основних проблем мета когнітивного напрямку існує суттєва проблема у здатності суб'єкта до метапізнавального сприймання та самосприймання. На думку дослідників, особистість, яка володіє мета когнітивними здібностями, здатна ефективно, а головне самостійно сприймати та вирішувати велику кількість поставлених задач на основі так званого ментального досвіду та за допомогою уже власне створених стратегій та планів які виникають у людини у процесі діяльності. I тут велику, а можливо і ключову роль відіграє самооцінка особистості, яка у взаємозв'язку власного управління свого пізнання, дає можливість підвищувати рівень успішності діяльності, для дітей це зокрема навчальної. Адже, на думку дослідників, віра у свої власні сили та можливості а також адекватність сприймання ситуації, дають можливість дитині не лише на даний момент але і майбутньому правильно будувати свою інтелектуальну діяльність розуміючи про іiі наслідки та можливості у практичному впровадженні. Рефлексія власних знань, дозволяє суб'єкту розуміти свої можливості і таким чином стратегічно планувати пізнавальні дії. Самоуправління пізнанням зачіпає так зване «метапізнання в дії», тобто його власне дію, до складу якої входять знання про власне свої індивідуальні прийоми та стратегії організації та управління процесом пізнання і вирішення теоретичних та практичних задач у ході безпосередньої діяльності[6 С.352].

У психології існує так звана концепція інтелекту М.А. Холодної. Яким же чином вона взаємопов'язана 3 нашим дослідженнями у галузі мета пізнання. Спробуємо наразі розібратись. М.А. Холодна, розглядає у робочій структурі інтелекту, метакогнітивний досвід як регулюючий фактор власного сприйняття метакогнітивного досвіду у діяльності особистості. Мимовільний та довільний інтелектуальний контроль - здібності які сприяють активізації власних дій та стратегій 
спрямованих на створення способів та досягнень різного роду завдань. Саме осмисленне та усвідомленне сприйняття власної інтелектуальної діяльності і $є$ метакогнітивною здатністю людини за висновками представників інтелектуальної теорії[5, с. 244-248, 6, с.352 ].

Аналіз останніх досліджень в галузі метапізнавальних процесів, дає можливість звернути увагу на теорію Т.Е. Чернокової. Сам процес метапізнання розглядається дослідницею, як накопичення інформаційних знань суб'єкта власне про пізнавальну діяльність як таку загалом, а також про особливість психічної сфери суб'єкта, яка дозволяє суб'єкту пізнавальної діяльності регулювати їі, відтворювати у потрібний момент, припиняти іiі та безпосередньо застосовувати. Сама ж структура метапізнання за Т.Е. Черноковою має наступні складові - це контроль та програмування дій, а також ціле покладання. Також слід відмітити, що дослідження проводились науковцем із дітьми дошкільного віку починаючи iз 4 -5 років, що дає можливість відслідковувати вікову періодизацію становлення саме мета когнітивного досвіду у процесі навчальної діяльності загалом. [7 с.155-158].

Особливу увагу вивченням метапроцесів сучасні дослідники зокрема вітчизняні приділяють аналізу метакогніцій під час навчальної діяльності зокрема дітей шкільного віку.

Є. Савін та А. Фомін, аналізуючи дослідження метакогнітивних процесів у сфері освітньої діяльності можливість впливу метакогнітивних знань педагога на учбову діяльність учнів, а також на розвиток мета пізнавальних процесів у дітей, які можуть змінюватись під дією мета когнітивного досвіду наставника. Також дослідники працюють у напрямку розробки спеціальних навчальних методик, які у майбутньому можуть покращити процес розвитку метапроцесів у ході навчальної діяльності [4, с.6-7].

М. Кашаповим введено поняття так званої абнотивності яка включає в себе креативність педагога, а також усвідомлення значимості творчого розвитку дітей при реалізації професійної діяльності. Креативність він розглядає як мета креативність тобто мета когнітивну здібність суб'єкта педагогічної діяльності. Сама суть мета креативності полягає у рефлексії власної обізнаності, і проявляється у високому рівні саморегуляції. Метапам'ять як метакогнітивна здібність суб'єкта педагогічної діяльності у школі проявляється у реалізації прагнення до формування метамнемічних здібностей у суб’єкта навчально-професійної діяльності. Метамислення - це мисленнєві дії над мисленням, здатність суб'єкта самостійно планувати пізнавальну діяльність і на рефлексивному рівні аналізувати іiі. Метамислення як метакогнітивна здібність суб'єкта педагогічної діяльності проявляється у реалізації прагнення до формування метамисленнєвих здібностей у суб'єкта навчальної діяльності [8, с. 384].

Висновки та перспективи подальших досліджень. Людина, що володіє метакогнітівними здібностями, повністю управляє своєю поведінкою. Метакогнітівно обдарований суб'єкт може правильно оцінити, важливість першочергових завдань у процесі пізнавальної діяльності таким чином спланувати подальшу мисленнєву діяльність. Багато численні дослідження показують, що у досліджуваних, яких безпосередньо навчали метакогнітівним навичкам, покращуються загальні показники успішності при вирішенні завдань інтелектуального характеру. Актуальним постає питання впровадження навчання під час якого відбувається не просто нагромадження величезного багажу знання, а вміння планування та прогнозування власної інтелектуальної діяльності. Розвиток метакогнітивних здібностей починаючи, ще 3 початкової школи дозволить в майбутньому ефективніше використовувати ресурси власної інтелектуальної діяльності при вирішенні не лише освітніх завдань але й розв'язанні повсякденних проблемних питань. Аналіз теоретичних концепцій у галузі мета пізнання, також дають змогу окреслити нові перспективи досліджень спрямованих на поглиблене вивчення саме метакогнітивних здібностей на різних вікових етапах.

\section{ЛІТЕРАТУРА}

1. Довгалюк Т.А., Волошина В.О Поняття мислення як мета когнітивного процесу у психологічній науці //«Молодий вчений» № 10 (25) Частина2 жовтень, 2015 р.

2. Зотова В.А.К вопросу о структуре метакогнитивных способностей Перспектива-2013: материалы Международной научной конференции студентов, аспирантов и молодых учёных. - Т. І. - Нальчик: Каб.-Балк. ун-т, 2013. - 413 с.

3. Зотова В.A. Метакогнитивные способности: анализ концепций: http://lomonosovmsu.ru/archive/Lomonosov_2013/2233/54600_e297.pdf. 
4. І. Д. Пасічник, Р. В. Каламаж, М. М. Августюк. Метакогнітивний моніторинг як регулятивний аспект метапізнання // Наукові записки. Серія «Психологія та педагогіка» Випуск 28 - Острог: Видавництво Національного університету «Острозька академія» -2014p. С.6-7

5. Савин Е. Ю. Уверенность в знании как аспект метакогнитивного мониторинга в учебной деятельности студентов / Е. Ю. Савин, А. Е. Фомин // Научные труды Калужского государственного университета имени К. Э. Циолковского. Серия: Психолого-педагогические науки. - 2011. - С. 244-248.

6. Карпов А.В. Психология метакогнитивных процессов личности/А.В.Карпов, И.М. Скитяэва.- М.: Изд-во «Институт психологи РАН», 2005. - 352 с.

7. Чернокова Т.Е. Метакогнитивная психология: проблема предмета исследования //Педагогика.2011. №3.c.155-158.

8. Кашапов М.М. Творческая деятельность профессионала в контексте когнитивного и метакогнитивного подходов /М.М. Кашапов // Под науч. ред. проф. М.М. Кашапова, Ю.В. Пошехоновой. - ЯрГУ: Ярославль, 2012. - 384 с.

9. Чернокова Т.Е. Проблема классификации метакогнитивных процессов: http://www.rusnauka.com/10_DN_2012/Psihologia/7_106695.doc.htm.

10. Холодная М. А. Психология интеллекта: парадоксы исследования. 2-е изд., перераб. и доп. - СПб.: Питер, 2002. - 272 с.

11. Хомуленко Т.Б. Метапам'ять: наукові підходи та експериментально-інтроспективна методика дослідження / Т.Б. Хомуленко, Т.І. Доцевич // Серія «Психологія». - 2014. - № 49. - С. 193-211.

12. Brown A. L. Metacognition, executive control, self-regulation, and other more mysterious mechanisms / A. L. Brown // In F.E. Weinert, R. Kluwe (Eds.), Metacognition, Motivation, and Understanding. - 1987. Hillsdale, NJ: Erlbaum Associates. - P. 65-116.

13. Brown A. Communities of learning and thinking, or a context by any other name / A. Brown, J. Campione // Developmental Perspectives on Teaching and Learning Thinking Skills / In D. Kuhn (Ed.). - Basel: Karger, 1990. - $396 \mathrm{p}$

14. Hacker D. J. Metacognition in education: A focus on calibration / D. J. Hacker, L. Bol, M. C. Keener // In J. Dunlosky and R. Bjork (Eds.), Handbook of Memory and Metacognition. - Mahwah, NJ: Lawrence Erlbaum Associates, 2008. - P. 429-455.

15. Sternberg R.J. Inside intelligence. American Scientist, 74,1986, $137 \mathrm{p}$

16. Wilson, J. Defining Metacognition: A step towards recognising metacognition as a worthwhile part of the curriculum: http://www.pemea.org/docs/V2_Assessment-Handbook.pdf.

17. Flavell J.H. Cognitive monitoring // children's oral communication skills. Academic Press. 1981. P. 35-60.

18. Flavell J.H. Metacognitive aspects of problem solving // The nature of intelligence. N. Y., 1976. P. 231-235.

19. Flavell J. H., Wellman H. M. Metamemory / In: Kail R. V. and Hag-en G. W. (Eds.) // Perspectives on the development of memory and cognition. - Hillsdale, N. Y.: Erlbaum, 1977. - p. 3-34. 